Article

\title{
History of Management and Stratigraphy of Organizing. The Venice Arsenal between Tangible and Intangible Heritage
}

\author{
Luca Zan \\ University of Bologna, Department of Management, Via Capo di Lucca 34, 40126 Bologna, Italy; \\ luca.zan@unibo.it; Tel.: +39-051-209877
}

Received: 21 February 2019; Accepted: 16 April 2019; Published: 19 April 2019

\begin{abstract}
The purpose of this contribution is to analyze the role of the Arsenal in the history of management, still underrepresented in international historiography, and link it to the literature on industrial heritage. It is this central role in the history of management that endows the Venice Arsenal with particular significance as intangible heritage. Discussing specific problems related to the research and interpretation of this intangible significance, in a context of stratification of levels of organization over time, this paper considers some implications for restoration of the Arsenal, as well as area to preserve this intangible heritage in terms of research, documentation, and presentation needs.
\end{abstract}

Keywords: heritage management; intangible heritage; management history; Venice Arsenal

\section{The Venice Arsenal at the Crossroad of Several Historiographies}

This paper offers some reflections on the significance of the Venice Arsenal from the point of view of the history of management and organization, relating this perspective to the current debate on the Arsenal in the industrial heritage literature.

The Arsenal itself is an important reference point in many historical traditions. It played a crucial role throughout the history of the Republic as a base for the sea power that characterized its development from the beginning to its collapse in 1797 (e.g., [1-7]), or in its renewed position after the Royal Navy was constituted following the creation of the new nation [8-12]. The Arsenal has been extensively investigated in terms of the history of architecture and urban studies, and its continuous transformation from its origins to the present day has been observed [13-16]. A few economic historians were also interested in its role in the evolution of the Republic [17,18]. In this context, attention focused on the knowledge and skills that developed over the centuries in what was known as the "officina dee meravegie" (workshop of wonders: [2,3,14,18-21]). However, specific investigation into the managerial, organizational, and accounting aspects of its history took place relatively late [21-23].

With the decline of its economic activity after WWII, the Arsenal began to be viewed in terms of industrial heritage [24,25]. Its majestic dimensions underline the importance of the Arsenal from this point of view: an area that covers about one tenth of the whole city [26]; a complex that has no equal in the world in terms of conservation [27], thanks to the fact it was operating in its original function of shipbuilding until a few decades ago. In particular, around the 1990s, manifold projects, ideas, and preliminary plans emerged in terms of possible reuses of the complex [27-35]. Starting with a work by Chirivi [24], a further historiographical tradition has thus developed in the last forty years.

Two aspects can be pointed out in terms of industrial heritage perspective. On the one hand, nothing has actually happened so far: a huge policy debate started in the 1990s and ended in 2015 with an updated sort of master plan by the municipality [36]; then everything stopped. On the other 
hand, a view of the Arsenal in its tangible aspects appears to have prevailed throughout the debate there. There is, however, less awareness of the historical importance of the Arsenal in more subtle aspects which can be defined as intangible heritage, and in particular in the historical contribution of the Arsenal in the evolution of management concepts.

Indeed, the importance of the Venice Arsenal in the history of management at the international level tends to be overlooked (despite appreciable insight in a few contributions (e.g., [3,14,20,37])). Between the 15th and 16th centuries, some discussion emerged about the issue of managing this protoindustrial complex, anticipating by three centuries what would become normal reference in economic, business, and accounting history [21]. The abrupt reconstruction of the Ottoman fleet after the battle of Lepanto in 1571 put the production processes at the Arsenal under particular pressure, in order to have a reserve fleet of 100 small galleys, plus 12 large ones in case of war. A truly challenging goal that was never achieved. However, this entailed the need for systematic reporting of the activities carried out: accounting for the production of the 100 plus 12 galleys triggered the development of a set of management notions and concepts.

It is this discorso del maneggio, as it was called ('handling', literally, but then leading to the English term 'management'), which represents a fundamental element of the intangible significance of the Arsenal's heritage.

\section{Methodological Notes}

This paper draws on the author's prolonged research on the Venice Arsenal. First, in-depth archival research was carried out at the State Archives in Venice starting from 1994, leading to two international publications [21,23], plus a book in Italian [22] (particularly interesting for readers of Italian in the 200-page documentary appendix).

Second, the findings emerging from this research were reported drawing some comparisons within the international debate, and in particular addressing the issue of Anglo-centrism and the lack of interest in what happened outside the Anglo-American world (and languages others than English) in the management and accounting literature. Later, further intensive archival research was carried out in two projects relating the findings of the Venice Arsenal research to a less West-centric view; on the one hand, examining how these aspects impacted the Great Divergence Debate between East and West [38] and, on the other hand, taking into account administrative traditions totally ignored in the dominant administrative literature, but which could be comparable-the Ottoman tradition, for example - and the organizational efforts in rebuilding the fleet after the Lepanto defeat [39].

Finally, in recent years, interest in management history (and the Venice Arsenal) has been linked to another (and major) research concern of the author regarding the management of arts organization and heritage, with long-term fieldwork, within an international research perspective $[40,41]$. In this regard, the whole debate on restoring the Arsenal has entered the agenda, with extensive documentary analysis and field work [42,43].

\section{The Venice Arsenal and the History of Management}

In general, management studies tend to give an a-historical representation of their nature [44]. A possible historical reconstruction of the evolution of this body of knowledge is out of the mainstream [45]: while the etymology of the term itself is rarely questioned, never seen as problematic, long-term archival and document research is rarely carried out, with little interest in protoindustrial settings. ${ }^{1}$

1 A former editor of one of the most important international journals on management, once asked in an email with disarming naivety: "Can you please elaborate on what you know regarding the origin of the term management...have long wondered!" 


\subsection{Managing: An Old Conundrum}

One answer is purely linguistic. For example, referring to the definitions in English dictionaries “manage: 1561, probably from It. maneggiare 'to handle,' especially 'to control a horse,' from L. manus 'hand' (see manual). Influenced by Fr. manège 'horsemanship' (earliest English sense was of handling horses), which was also from the Italian. Extended to other objects or business from 1579. Slang sense of 'get by' first recorded 1655" [46]. ${ }^{2}$

On the other hand, we can recall that the Spanish term manejo expresses exactly the English term 'management'. In Italy, the term seems to have maintained this meaning at least until the 19th century. A plaque inside the Arsenal (Figure 1), located near the main entrance and dated 5 June 1743, reports that "Gabriele di Ferdinando, a worker in the Arsenal armory, was banished upon penalty of hanging as an unfaithful administrator and guilty of enormous prejudice committed in the maneggio of public money". ${ }^{3}$

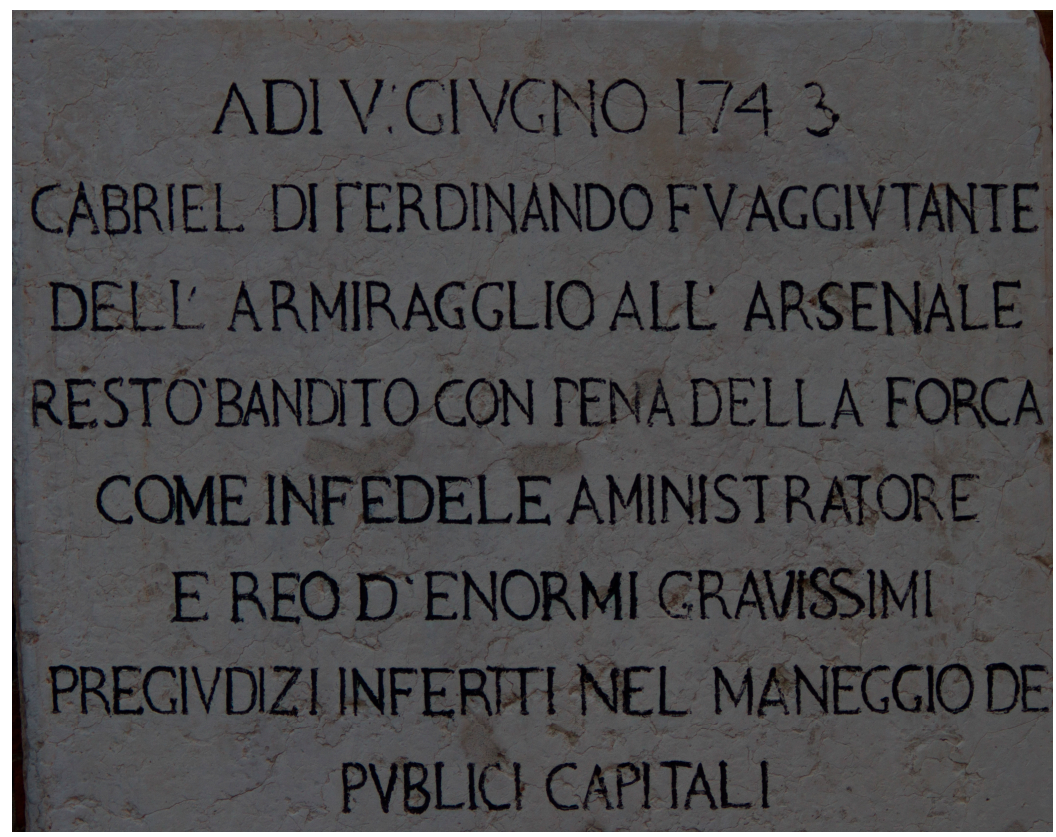

Figure 1. Memorial plaque inside the Venice Arsenal.

Likewise, a legacy text displayed at the Ethnographic Museum of Ostana, Alta Valle Po (Figure 2) features the interesting title "Book containing the maneggio [handling/managing] and carrying out of wills" [48]. If today the current use of the term in Italy seems to be predominantly relegated to horse riding, this forgotten meaning is however still present, and emerges from the comprehensive definition that can be found in the Treccani Dictionary before moving on to more modern definitions: "maneggio m. noun [der. from to handle.]) -1. a. Handling, the action of handling especially as the use of objects or instruments according to a specific technique, generally applied with skill: to be trained to handle weapons, swords, oars; skilled in the handling of brushes, in the fig. sense, handling a language, as in the appropriate use of it. In particular, in string musical instruments, bowing exercise. b. Conduction, management, administration: the handling of business, of public affairs, of public administration (real

2 More intricate is the definition of the Online Etymology Dictionary [47], which would call for thorough analysis of its sources: "management 1598, 'act of managing,' from manage (q.v.). Meaning 'governing body' (originally of a theater) is from 1739. Manager is 1588 in the sense of 'one who manages;' specific sense of 'one who conducts a house of business or public institution' is from 1705."

3 "Gabriele di Ferdinando fu aggiutante dell'armiragglio all'Arsenale restò bandito con la pena della forca come infedele aministratore e reo d'enormi gravissimi pregiudizi infertti nel maneggio de publici capitali". 
and fig. the handling of money), the handling of the house, of a house (see the corresponding French term ménage)". 4

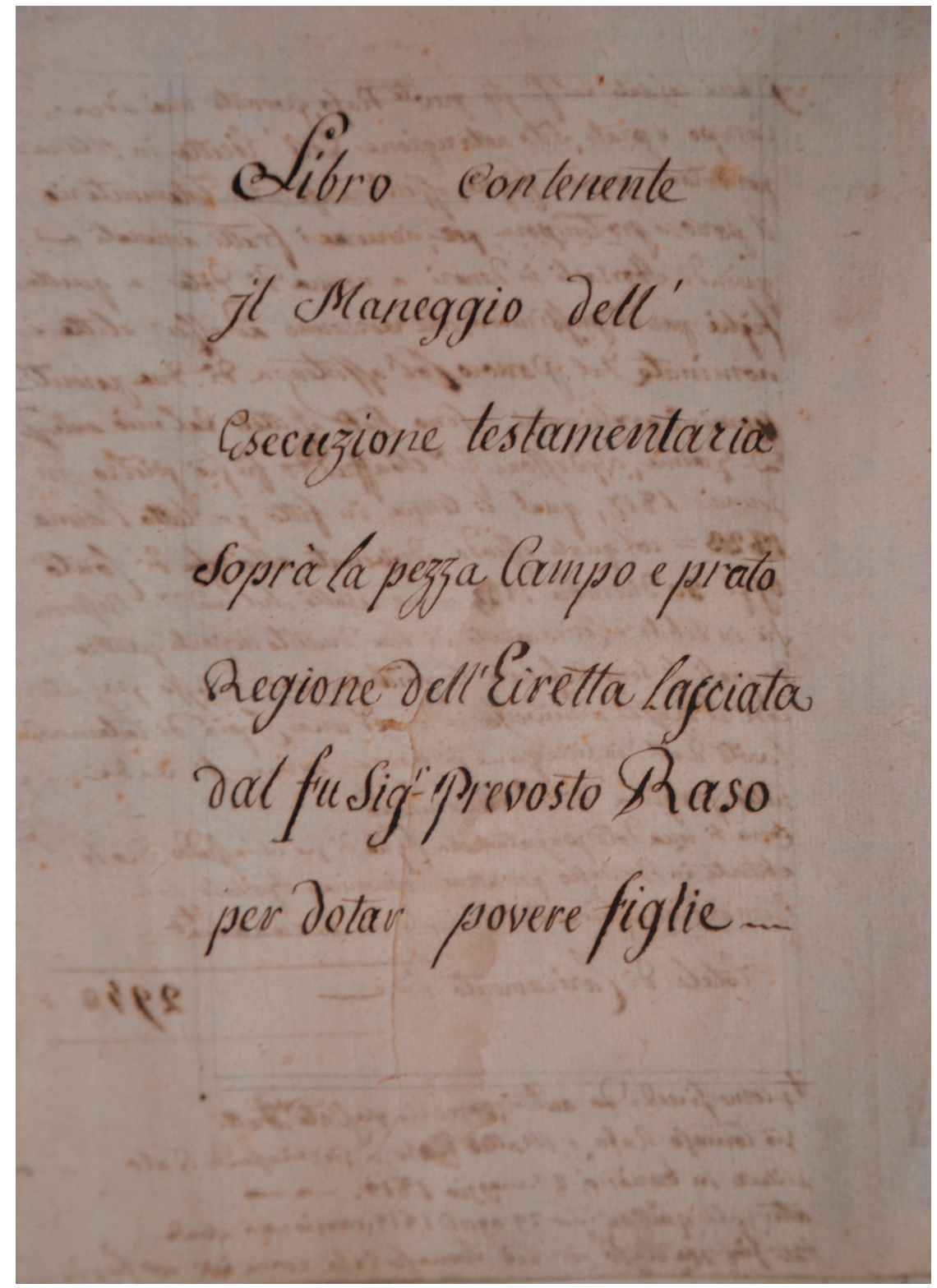

Figure 2. A legacy text from the end of the 19th century (Civico Museo Etnografico, Ostana, Cuneo, Italy).

However, another answer is perhaps more interesting, and involves investigating the different meanings that the term has covered in the writings of the officers of the Renaissance, in particular at the Venice Arsenal. Here the paper draws on what was already documented in [21-23].

4 “manéggio s. m. [der. di maneggiare]. - 1. a. Il maneggiare, l'azione del maneggiare, soprattutto come uso di oggetti o strumenti secondo una determinata tecnica, applicata in genere con perizia: addestrarsi al $\mathrm{m}$. delle armi, della spada, del remo; essere abile nel $\mathrm{m}$. dei pennelli; in senso fig. $m$. della lingua, uso appropriato di essa. In partic. negli strumenti musicali a corda, esercizio di archeggiamento. b. Conduzione, gestione, amministrazione: il m. degli affari, della cosa pubblica, della pubblica amministrazione (tra proprio e fig. il m. del denaro); il m. della casa, di una casa (cfr. il corrispondente termine fr. ménage)" [49] (italics in the original). 


\subsection{Some Examples of Innovation in the Knowledge about Managing at the Venice Arsenal (1586/1633)}

Pacioli [50], in the first printed book on the double-entry bookkeeping system, used the term maneggio. ${ }^{5}$ In 1586, almost a century later, Baldisserra Drachio [51] wrote an important internal document on the managing of the Arsenal, in which he not only explicitly used the term maneggio, but also extensively described some concepts that can be found in today's management 'tool-kit':

- " "del modo di conservar li roveri" concerns matters that today we would define as pertaining to the logistics of raw materials, from acquisition to transport, and storage at the Arsenal;

- "della misura ordinaria delle galee" concerns the need to define single, common timber ("il sesto comune") for the galleys produced in the Arsenal;

- "del modo di separar le galee nove dalle vecchie et accomodarle nei squeri con li legnami segati" deals essentially with what we would now define as the production layout, with the definition of areas for the production of new galleys and the maintenance of the old ones, and with adequate placement of the materials sorted by type;

- "delle maestranze et dell'ellettione a diversi carrichi" defines the composition of the work teams, with an early but precise example of organization of labor;

- "della ellettione delli reformatori et creation d'uno sopraintendente et conoscitor universal dell'arsenale" deals with the question of combined control over the entire complex, anticipating one of the most difficult questions of the whole modern organizational dilemma, namely the arrangement of power and responsibility within an organization.

In two major texts a few years later, Bartolomeo Tadini, chief accounting officer at the Arsenal, introduced important ideas regarding the monitoring of workers and materials. With rare clarity, the 1593 document [52] explains the problem, developing it analytically in the following pages: "La spesa della Casa dell'Arsenal, importantissima, consiste in maistranze et robbe" (The great expense of the Arsenal House consists of workers and materials). Detailed practical proposals for monitoring were thus presented: On people, monitoring was to incentivize weekly presence and activities. As for materials, monitoring and inspections were carried out to reduce waste. In the 1594 document [53], a temporary two-year reform of the organization of labor was suggested for production of the reserve of $100+12$ galleys. A forecast was provided (a budget, as we would call it today) regarding the expenses for the staff and a comment on possible ways to save money (Figure 3). Interestingly, the proposed temporary structure is based explicitly on "order, competitions, prizes and punishments"; the latter term is still in use in Italy to indicate what is called in English a 'reward system'.

5 For example: “Delle quali la potissima è la pecunia numerata e ogni altra facoltà sostanziale, iuxta illud phy. unum aliquid necessarium est substantia, senza il cui suffragio mal si può il maneggio trafficante esercitare..." "Of which the main reason is recorded money, and any other substantial faculty, iuxta illud phy. unum aliquid necessarium est substantia, without record of which the handling of traffic cannot be exercised") [50] (p. 34); "Il qual Cavedale in tutti i principii di Quaderni e Giornali mercanteschi sempre deve essere posto creditore, e la ditta Cassa sempre deve essere posta debitrice. E mai per nullo tempo nel maneggio mercantesco la Cassa può essere creditrice..." ("The Capital must always be a creditor in all notebooks and Mercantile papers, and the Cash must always be a debtor, and never can it be a creditor... ") (p. 58) "Delle partite famose e particolari nel maneggio trafficante, come sono baratti, compagnie... come le si abbino a assettare e ordinare ne' libri mercanteschi, e prima de' baratti semplici, composti e col tempo con aperti esempi di tutti in Memoriale, Giornale e Quaderno..." ("Of the famous and particular exchanges in handling such as barters, companies... as they combined to put the records in order, and first simple and compound barters, and over time with open examples of all in the Memorials, Journals and notebooks...") (Title of Chapter XX, p. 85). 


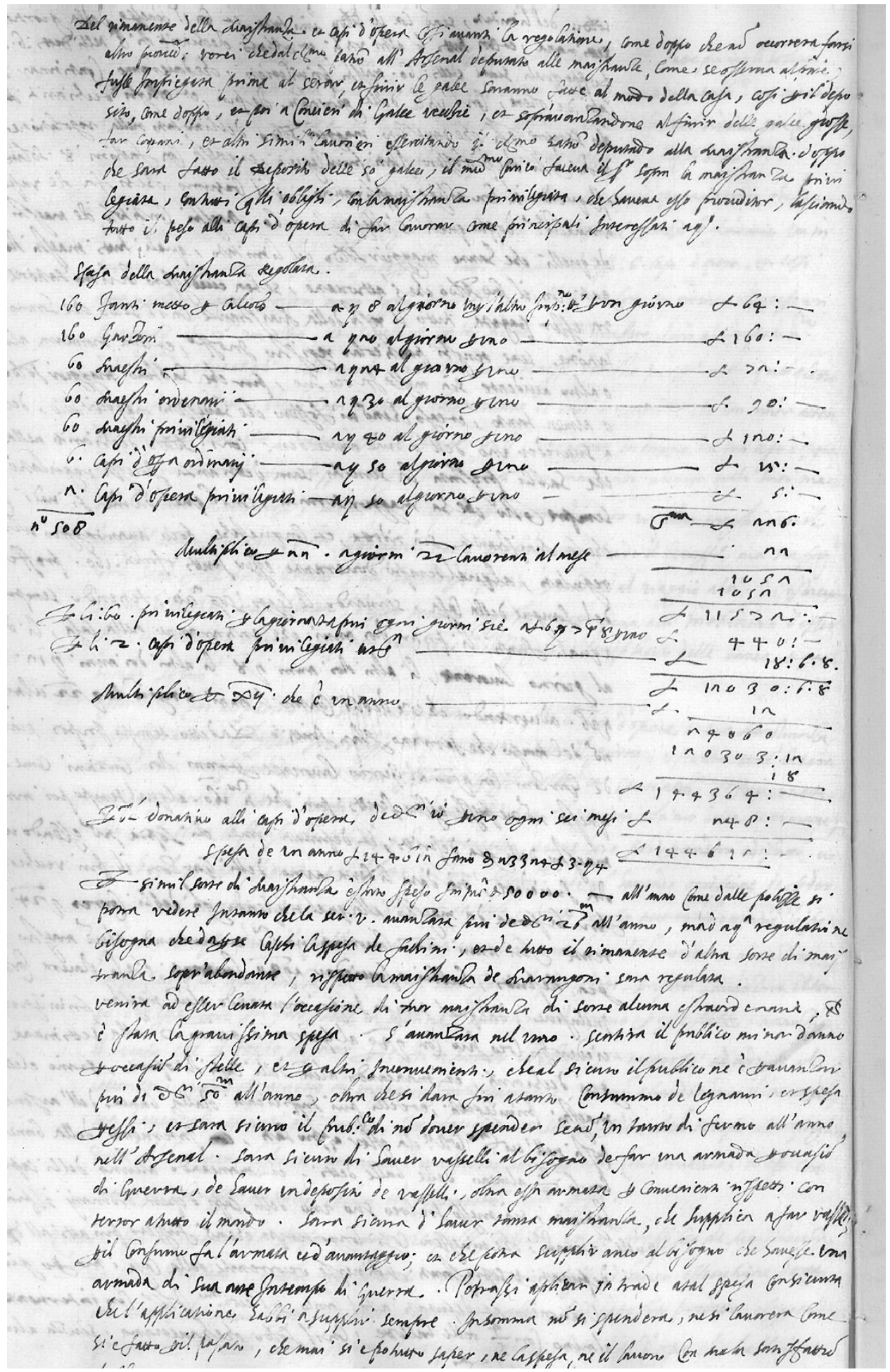

Figure 3. The expenses related to the proposed reorganization by Bartolomeo Tadini in 1594 [53] (A.S.Ve, Patroni e Provveditori all'Arsenal, b. 533).

Another relevant document is the report by Alvise Molin in 1633 [54], where the cost of raw materials and ships (distinguishing between large and small galleys) is explained and discussed, with two further conceptual innovations in terms of management: Progress was measured in man-months as opposed to the physical description of the production phase that was previously used, and calculation was applied to human resources, which thus became a 'factor' of production and as such an object of 
calculation (for example as a basis for the definition of production capacity or the needs of sizing the workforce). ${ }^{6}$

In short, towards the end of the 16th century, the Venice Arsenal was one of the most important sites in the world in terms of the development of modern managerial and accounting knowledge, including issues that we would now define as logistics, layout, standardization, management, planning, costs, progress, budget, and organization of labor. This is an incredible body of knowledge, certainly for management studies, but from our point of view here represents elements of 'outstanding universal value' in the intangible heritage associated with the tangible remains of the Arsenal.

\subsection{Management and Accounting Historiographies: A Lack of Attention}

This extraordinary intangible significance of the Arsenal tends to be overlooked in the literature, both within the community of management and accounting scholars, and the community of heritage scholars. The latter can be partly excused given the failure of the relevant experts (management and accounting as well as economic and business historians) to raise the question. On the other hand, the unresponsiveness of the international community of management, accounting, and business history scholars is simply unacceptable.

Indeed, management literature very rarely investigates the historical development of management knowledge over time (for a more extensive critique: [45]). When the question is addressed, the answers are disheartening: for Ansoff [55] everything began in the 20th century while Pfeffer [56] -in an article of great value in terms of field research methodology — refers to the "60 years" of management history! Moreover, in the rare cases of discussion of management history, reference is more to the history of thought (with the inevitable reconstruction from Taylor, Ford, Fayol, etc.) than the history of practices. Furthermore, until a few decades ago Anglo-Saxon accounting historians showed a colonialist attitude on the subject, referring only to the existing literature in English. Aside from a bow to the 'founding father' of double-entry bookkeeping, they go on with references, periodization, concepts, and authors that have nothing to do with the continental traditions on the history of accounting, including for example, the Italian one. This is a curious position that, with some irony, has been labeled as "After Paciolo, nothing" [57]. ${ }^{7}$ No historicization would be better than false historicization, which is often found in important accounting and management books, riddled with statements that do not survive the empirical evidence of the early 17 th century Venice Arsenal. ${ }^{8}$

It is curious that even Chandler himself-the most important business historian-never felt the need to refer to what had developed at the Venice Arsenal three centuries before the English industrial revolution first and the American managerial revolution after. Ignorance is never a valid excuse, yet in this case the friendship with Frederick Lane from the John Hopkins University in Baltimore-probably

6 "Of small galleys Your Highness has a hundred and three; fifty eight of these are new but not yet supplied, and it will take months, if not years, for them to be perfected; twenty of these shall be ended in four months; thirteen more, with seventy workers, will be provided in three months and another twenty-five require long labor and many workers that in the present scarcity cannot match up to the need, as I shall illustrate to Your Excellency" [53].During a presentation of my research at the University of Princeton a few years ago, one of the best-known American experts on the history of Venice sincerely confessed: "I never thought accounting was in such a process of change at that time".

7 See, for example, the page "History of Accounting From Ancient Times to Today. The Medieval and Renaissance Revolution of Bookkeeping" [58] where, save a brief reference to Leonardo da Vinci, you go directly from Pacioli to the 1854 Order of Accountants in Scotland, clumsily sold as the first professional organization of accountants by ignoring the 1581 Collegio dei Rasonati of Venice in Campo San Bortolomio.

8 See, for example [59] (pp. 6-7): "Before the 19th century, all exchanges took place between a merchant-entrepreneur and people who did not belong to the organization... All exchange activities were carried out in the market and it was easy to be successful... For the entrepreneurs... as a consequence of the industrial revolution and the possibilities to profit from the economies of scale, it became convenient to invest considerable capital in production... The vitality and success of the organizations thus managed showed what profits could be achieved by managing a hierarchical organization...The birth of these organizations over 150 years ago created a new demand for accounting information... it was a need for measurements that was created to determine the price for the output produced by an internal activity... Entrepreneurs developed short indexes through which work and materials were converted into finished products, evaluations that were also used to motivate and evaluate managers." 
the greatest scholar of Venice and the Arsenal-does away with any suspicion of ignorance, suggesting a sort of vested intellectual interest [45] that made it convenient to ignore the anomaly of the Arsenal with respect to the overall Chandlerian framework of the history of the great enterprise. ${ }^{9}$

In short, management scholars need to go back to the historical roots of management, reopening research perspectives, and possibly overcoming Anglo-centrism or West-centrism. This also means-even for the community of heritage scholars, as far as this paper is concerned-fully recognizing the central role that the Venice Arsenal has played in the history of management, and therefore recognizing the significance of the intangible heritage that characterizes this place.

\section{Between Tangible and Intangible: Problems in Research and Narration}

Recognizing the intangible significance of the Arsenal opens up methodological problems regarding research and understanding connected to the complexity of the site. As discussed above, the Arsenal is two things at the same time, both of extraordinary importance. It is an 'archive of artifacts', buildings and material structures, that constitute the significance of the tangible heritage. At the same time, it is also an 'archive of knowledge' which stands for the intangible heritage- conversations about managing/handling as well as technical-productive knowledge.

Over time the two aspects (tangible/intangible) show marked historical processes of transformation, adding an additional layer of complexity in the interaction between them. The continuous (and partly visible) architectural transformations were associated with subtler (intangible) transformations in the technical-productive know-how, and in particular in the centuries-long matter of management, calling for an original approach that could be defined as 'stratigraphy of organizing'. The two aspects are confused, so rich in contents as to be difficult to interpret/narrate.

\subsection{General Problems in the History of Management}

The history of management in itself presents some difficult problems. In American jargon, management can be defined as 'getting things done', a superficial definition which nonetheless captures important aspects in management, focusing on actions more than simply on wishing, thinking, and planning. In a more sophisticated way, March [62] identifies the essence of management as a problem of 'focusing attention'; others as an issue of 'organizing' (e.g., [63]).

The history of management is therefore the evolution in the ways of focusing attention over time; it is the dynamics of attention itself. Yet how can you track the development, the history of attention in a specific site or context? How can the story be told? This is not easy for the historian to reconstruct, for example in terms of processes structuring space, time, and resources (layout, work organization, allocation of resources, monitoring). Comparatively speaking, the history of architecture is based on 'harder' (and tangible) data: you can see artifacts or ruins (e.g., walls, stones, projects) and you can see the changes over time (see e.g., [64]). For the management historian, there is only an abstract concept of attention, which is not immediately and totally reflected in the 'hard data' that remain. An example is the invention of the concept of 'work in progress' or 'cost', which does not leave any marked traces in artifacts.

9 Indeed, even Chandler's following observations do not withstand the archival evidence that emerged from the research on the Venetian Arsenal: "The modern company saw its first historical appearance when the volume of commerce reached a level at which managerial coordination became more efficient and profitable compared to co-ordination through the workings of the market" [60] (p. 49 It. ed.). Or: "Before 1840, the factory with a permanent and numerous workforce (as well as considerable amounts of fixed and circulating capital) remained concentrated in the textile sector only. Due to the small size of the company in the period prior to the mid-19th century, specialization was limited to the business. The business was managed by the owners, while the need for an accurate and detailed internal organization, detailed statistical data, and cost calculation methods was not felt yet, although it has become a pre-requisite of the modern company" [61] (p. 20). 


\subsection{Problems that are Specific to the Venice Arsenal}

The greatest difficulties in understanding the manifold significance of the Arsenal are paradoxically linked to its survival in forms rarely found elsewhere. A complex that is old and enormous yet relatively well-kept over the centuries - thanks to its isolation and its continuous use as a production site and barracks ${ }^{10}$ — has in the last few decades been restored more than is generally imagined $[42,64,65]$.

To the expert observer, the complex offers an incredible amount of information to be savored or glimpsed: the passing of time, the impact of transformation over centuries, and the endless history of the complex as a whole and of individual buildings, in a confused mix of uses and reconstructions up to the latest decades (well-described by historians of Venice architecture). This is a place, however, where what is visible hides (and makes it even more difficult to understand) what is invisible, where the tangible hides the intangible in their partly independent histories; for example, in terms of the organization and division of labor whose features, especially in the Middle Ages, can hardly even be imagined today. Then there is the allocation of space: in this regard, the famous 1797 painting by Maffioletti (Figure 4) can only be understood in the light of the flow of documents and considerations on management, if not in relation to the discourse on managing/handling inside the flow of documents, which developed as from a resolution in 1580 and found expression in a series of periodic reports that are kept in the State Archives [25], including documents presented in Section 3.2 of this paper. This concern with management, which continued going through transformations in the 19th and 20th centuries, could be a key to further interpret the technological and production transformations that characterized the situation in a post-unification context as described by historians of Venice $[8,10]$, forming a sort of stratigraphy open to reconstruction of 'levels' and 'layers' in organization practices over the centuries.

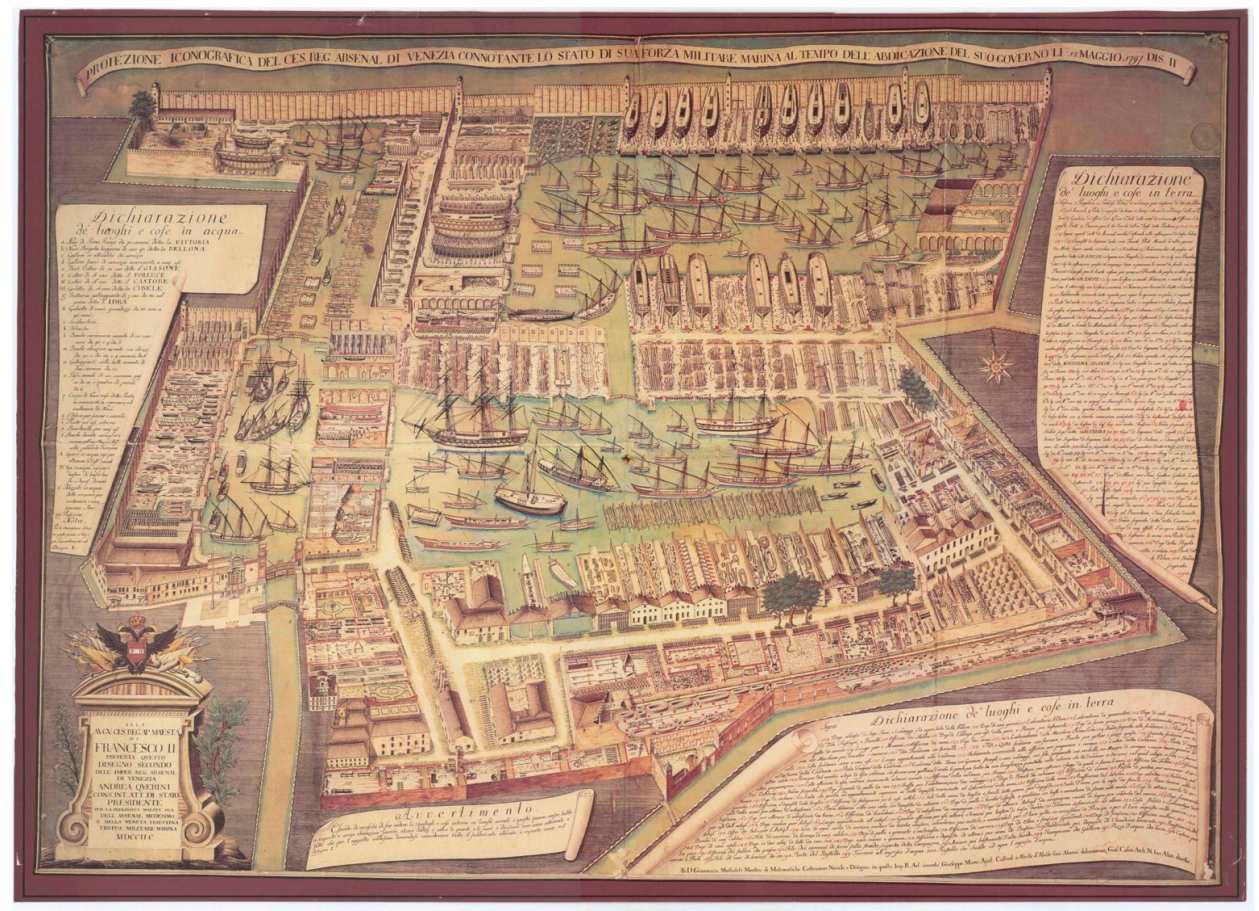

Figure 4. View of the Arsenal by G.M. Maffioletti, 1797 (Museo Storico Navale, Venice).

10 "The spatial isolation of the complex, its function as a ship factory, but above all its size has resisted minute and fragmentary transformations, preserving its structure intact but empty of every productive function" [32] (p. 5). In this context, "the Naval Command has made itself, de facto (and unexpectedly), beyond any intention or competence, a conserver of the old Arsenal" [27] (p. 13). 
Curiously, some attention has been paid to centuries-old family businesses (see for example [66] and the various traceable rankings $([67,68])$, while no interest has been shown in the value-historical and theoretical at the same time-of this centuries-old history of an entity of the state bureaucracy (a public manufactory of the Venice Republic, in this case) without which the subsequent development of family and private companies would have been unthinkable, despite the observations of Chandler, Johnson and Kaplan, and others [45]. ${ }^{11}$

Paradoxically, it is the wealth of contents in the site itself, its history, its events, and its evolution all the way to today's state of conservation that produces an excess of information, making interpretation of the site itself particularly difficult.

\section{The Needs of Research, Documentation, and Presentation of the Intangible}

In the desirable approach to restoration of the Arsenal [31,34-36,42,69-72] problems of research, documentation, and presentation arise, also with reference to the intangible component, more than is usually acknowledged. In terms of research, there is a need to develop coordination between different perspectives more systematically, both for the research already carried out and for the development of a possible research agenda, focusing on different periods-or at different levels of the organizing stratigraphy - where the persistence of organizing is crucial and not incidental.

In terms of documentation, there is a need to better structure and arrange sources of different natures available in various archives (for example, with regard to the materials relating to the post-unification period).

However, also in terms of presentation, the problem is how to narrate the intangible dimension of the Arsenal, and how to interpret and communicate the history of organizing and its stratigraphy. Here we go back to the possible reuses of the Arsenal, and how this can connect with the problem of narrating the intangible value of its heritage. Indeed, there is a middle ground between total musealization and a use that completely ignores (or hides) the intangible significance of the Arsenal; the intermediate solutions are likely to be just that (something between a visitor center and a 'not huge' museum).

This is a criticism that can be made of some large museum projects that were presented in the early 2000s, which involved an immense area of the Arsenal, with improbable forms of self-funding. Regarding these aspects, see the discussion held on 18 April 2017 at the Ateneo Veneto of Venice: "The future of the Venice Arsenal. What museum and what kind of accessibility?" [43].

However, criticism can be also made of uses that, in fact, deny access to a possible understanding of the Arsenal in terms of industrial archaeology, as in the case of the Biennale during which visitors to the Corderie could not perceive the historical building and its original uses. Indeed, during the exhibition, display requirements and installations lead to the introduction of panels and supports, useful to present the works on display but which interrupted perception of the length of the immense corridor, a unique and constitutive element of the complex (one of the longest buildings in the world). ${ }^{12}$ In any case, when there are no exhibitions the site is simply inaccessible. A similar fate is that of the old-and historically important-machine for the manufacture of ropes from the Corderia Inio mentioned by Tonini [73]. Purchased by the Venetian Civic Museums, after the first presentation it was dismantled. Now it lies (disassembled) in one of the military warehouses, "pro tempore" despite

11 From this point, the oft-quoted statement [66] proves a little dangerous, if understood as the exclusive presence of small businesses without complex and sophisticated forms of public administration and related organizations: "Before the multinational corporation, there was family business. Before the Industrial Revolution, there was family business."

12 The exception was the 2018 Architecture Biennale, offering for the first time an uninterrupted view of the entire length of the corderie (rope factory), as Claudio Menichelli pointed out to me (interview, 23 June 2018). 
insistent requests by Roberto D'Agostino at the time of the Arsenale Spa, ${ }^{13}$ and others expressed by civil society. ${ }^{14}$

\section{Conclusions}

The historical complexity of the Venice Arsenal poses considerable conceptual challenges, in which the idea of management recurs at different levels. Indeed, one could speak of a cycle of relevance when it comes to management: between (a) original significance, (b) historical preservation of the original significance, and (c) re-application of the same conceptual framework to new forms of reuse (Figure 5).

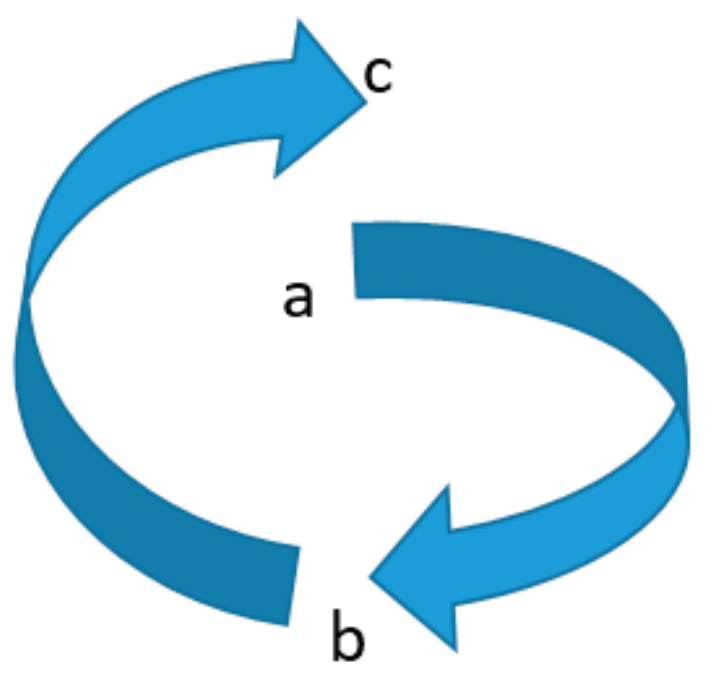

Figure 5. The relevance cycle of management at the Venice Arsenal: (a) management as conducted in the original production process and its transformations over time until the end of activity; (b) the problem of retaining the intangible significance of the complex in possible reuses; (c) the prospect for the feasibility of management in reuse projects.

To begin with, the aspect of management examined here, represents an original contribution to our understanding of the evolution of administrative, managerial, and accounting at the worldwide level (Figure 5a). For the first time, at the turn of the 16th century, not only was management implemented, but it was written about. It had to be reported, particularly with regard to the production of the $100+$ 12 galleys, thus constituting a cognitive laboratory that would in a few decades invent a language and reflections on management, centuries earlier than normally acknowledged. The original significance of the Arsenal in its 'tangible' dimension is closely linked to this intangible aspect. This relationship continued for centuries, until the mid-20th century, when the Arsenal gradually lost its original use as a production site.

Forms of preservation of the original significance become crucial even in this phase of redefinition of the uses of the Arsenal (Figure 5b). A process of 're-semantization' [74] of the old production site took place, for example according to the masterplan $[36,75]$ and in the modifications from the original 2001 version onwards. While cancellation of the tangible significance can be prevented with legislation on the cultural heritage, the same cannot be said for the intangible heritage, which calls for further

13 "The last rope-maker able to reassemble it lives in the town's retirement home. My attempts to move the machine to the Corderie, its natural place, and to entrust it to that rope-maker have failed" (interview with Roberto D'Agostino, 10 October 2018).

14 The lawyer Giorgio Suppiej of the Forum Futuro Arsenale has kindly sent me the link to the interview with Renzo Inio, the last "corder" (rope-maker) who had it installed at the time: https://www.youtube.com/watch?time_continue=708\&v= gn7CEWMZIw. 
attention to conservation in the process of redefining potential new uses, delineating what to preserve, research, document, and interpret, with all the difficulties inherent to the history of the intangible (and management in particular, in this case): not obvious, hard to study and explain.

With a degree of irony, the concept of management enjoys a sort of historical revenge, playing an essential role in any project of reuse of the complex, (re)introducing, albeit at different levels, a logic of economic feasibility of potential projects (Figure 5 c).

The introduction to this article mentioned two limits in the debate on the Arsenal from the point of view of industrial heritage: the fact that nothing really happened, from a policy point of view and the lack of reference to the intangible aspects, specifically in terms of the history of management perspective. The latter can be related to point (b) in the framework. The former, and the overall inability to act is explained, at least partially, by the total lack of understanding of possible managerial considerations: budget, alternatives, financial and institutional sustainability (Figure 5c).

Probably, the framework of Figure 5 can be applied to many other contexts in the industrial heritage field when adopting a specific organizational-managerial perspective. As businesses of their time and end products of the Schumpeterian creative destruction, the original uses of the heritage are inextricably linked to specific forms, practices, and contents of management-similar to the situation described in Figure 5a-although normally less innovative than the Arsenal at an international level. These aspects, however, must be reconstructed and narrated — and conserved — over and above generic reference to matters of 'valorization' (e.g., [76]), and then re-presented in the form of organizational and managerial knowledge in the redefinition of the possible reuses of the complex. In forms that should themselves be sustainable, also from a management (financial, organizational and institutional) point of view.

This would also open interesting options for the potential involvement of economics, business, or management scholars in the purely curatorial aspects, should they seriously take into consideration the historical dimension of their studies as depositaries of the specific historical significance of organization and organizing.

Acknowledgments: This paper is based on research work carried out as a visiting fellow at the Management Department of the $\mathrm{Ca}^{\prime}$ Foscari University of Venice in the first semester of 2018. I would like to thank the following institutions for allowing reproduction of images under their copyright: for Figure 2, the Archivio di Stato di Venezia; for Figure 3, the Civico Museo Etnogafico di Ostana, CN (thanks to Ilaria for retrieving the document and taking pictures); for Figure 4, the Marina Militare.

Conflicts of Interest: The author declares no conflicts of interest.

\section{References}

1. Nani Mocenigo, M. L'Arsenale di Venezia; Filippi: Roma, Italy, 1927.

2. Lane, F. Venetian Ships and Shipbuilders of the Renaissance; Johns Hopkins Press: Baltimore, Spain, 1934.

3. Lane, F. Le Navi di Venezia; Einaudi: Torino, Italy, 1969.

4. Lane, F. Venice. A Maritime Republic; Baltimore; The Johns Hopkins University Press: Baltimore, Spain, 1973.

5. Braudel, F. La Vita Economica di Venezia nel Secolo XVI. In La Civiltà Veneziana del Rinascimento; VV.AA.; Sansoni: Firenze, Italy, 1958.

6. Braudel, F.; Jeannin, P.; Meuvret, J.; Romano, R. Le déclin de Venise au XVII ${ }^{e}$ siècle. In Aspetti e Cause Della Decadenza Economica Veneziana Nel Secolo XVII; Luzzato, G., Bognetti, G.P., Eds.; Istituto per la Collaborazione Culturale: Roma, Italy, 1961.

7. Tenenti, A.; Tucci, U. (Eds.) Storia di Venezia, Vol. V, Il Rinascimento. Società ed Economia; Istituto dell'Enciclopedia Italiana: Roma, Italy, 1996.

8. Bellavitis, G. L'Arsenale di Venezia. Storia di Una Grande Struttura Urbana; Cicero Editore: Venezia, Italy, 1983.

9. Ventrice, P. L'Arsenale di Venezia e i cantieri navali della marina. Il Contributo Italiano Alla Storia del Pensiero. 2013. Available online: http://www.treccani.it/enciclopedia/l-arsenale-di-venezia-e-i-cantieri-navali-dellamarina_\%28Il-Contributo-italiano-alla-storia-del-Pensiero:-Tecnica\%29/ (accessed on 23 February 2019).

10. Ventrice, P. L'Arsenale di Venezia; Cierre Edizioni: Verona, Italy, 2009. 
11. Salvadori, A. L'Arsenal e l'industria navale. In Civiltà di Venezia, Vol. 2, Il Rinascimento; Perocco, G., Salvadori, A., Eds.; La Stamperia di Venezia Editrice: Venezia, Italy, 1987.

12. Ferrari Bravo, M.; Lalosevic, I.; Marsetič, R.; Pavićević, R. Dalla Serenissima All'aquila Bicipite; Bioblion Edizioni: Milano, Italy, 2012.

13. Casoni, G. Breve Storia dell'Arsenal di Venezia. In Venezia e Sue Lagune; Stabilimento Antonelli: Venezia, Italy, 1847; Volume 1.

14. Concina, E. L'Arsenale della Repubblica di Venezia; Mondadori Electa: Milano, Italy, 1984.

15. Vanore, M. (Ed.) HAULuP_ Heritage and Architecture of Urban Landscape under Production. Venezia Arsenale; Libellula Edizioni: Tricase, Italy, 2014.

16. Pizzarello, U.; Fontana, V. Pietre e Legni Dell'arsenale di Venezia; L'Altra Riva: Venezia, Italy, 1983.

17. Romano, R. Economic Aspects of the Construction of Warships in Venice in the Sixteenth Century. In Crisis and Change in the Venetian Economy in the Sixteenth and Seventeenth Centurie; Pullan, B., Ed.; Methuen and Co. Ltd.: London, UK, 1968; pp. 59-87.

18. Forsellini, M. L'organizzazione economica dell'Arsenale di Venezia nella prima metà del Seicento. Arch. Veneto 1930, 7, 54-117.

19. Caniato, G. L' Arsenale: Maestranze e organizzazione del lavoro. In Storia di Venezia, Vol. V, II Rinascimento; Tucci, U., Tenenti, A., Eds.; Società ed Economia, Istituto della Enciclopedia Treccani: Roma, Italy, 1996.

20. Davis, R. Costruttori di Navi a Venezia. Vita e Lavoro nell'Arsenale di Venezia, il più Grande Complesso Produttivo Preindustriale dell'età Moderna; Neri Pozza: Milan, Italy, 1997.

21. Zan, L. Accounting and management discourse in protoindustrial settings: The Venice Arsenal in the turn of the XVI Century. Account. Bus. Res. 2004, 32, 145-175. [CrossRef]

22. Zan, L.; Rossi, F.; Zambon, S. Il "Discorso del Maneggio". Pratiche Gestionali e. Contabili all'Arsenale di Venezia, 1580-1643; Il Mulino: Bologna, Italy, 2006.

23. Zambon, S.; Zan, L. Controlling expenditure, or the slow emergence of costing at the Venice Arsenal (1586-1633). Account. Bus. Financ. Hist. 2007, 17, 105-128. [CrossRef]

24. Chirivi, R. L' Arsenale di Venezia; Marsilio: Venezia, Italy, 1976.

25. VV.AA. The Edge of the Arsenal; Maggioli: Venezia, Italy, 1997.

26. D'agostino, R. Arsenale: Dallo Stato al Comune. In Il futuro dell'Arsenale di Venezia. Quale museo e Quale Accessibilità? Zan, L., Ed.; Cafoscarina: Venezia, Italy, 2019.

27. Pastor, V. L'Arsenale di Venezia. Progetti Tentativo; Il Poligrafo: Padova, Italy, 2017.

28. Gennaro, P.; Testi, G. Progetto Arsenale. Studi e Ricerche per l'Arsenale di Venezia; Cluva Università: Venezia, Italy, 1985.

29. Gennaro, P.; Semerani, L. L'Arsenale Riordinato. Nuovi progetti per Venezia; Arsenale Editrice: Venezia, Italy, 1987.

30. Lugato, D.; Ruol, M. (Eds.) L'Arsenale di Venezia. Una Metodologia per la Conservazione; Città Studi Edizioni: Milano, Italy, 1995.

31. Pini, D. Castello e l'Arsenale: Serve proprio un 'grande progetto'? In L'intorno dell'Arsenale; ILAUD: Urbino, Italy, 1999.

32. Lombardi, G.; Aymonino, C.; Bandarin, F.; Bellavitis, G.; Brant, A.; Fontanari, E. L'Arsenale di Venezia e l'Expo 2000. Progetto di recupero dell'Arsenale di Venezia per attività temporanee e permanenti nello scenario dell'Esposizione Universale del 2000, Sintesi del Rapporto Finale; Venezia, Italy. 2000. Available online: http://sbd.iuav.it/sbda/mostraindici.php?\&EW_D=NEW\&EW_T=TF\&EW_P=LS_EW\&EW=008921\& EW_INV=AA_CIA_000002051\& (accessed on 15 April 2019).

33. Chen, A.H.; Calzolaio, F. Progetti per L'arsenale di Venezia; Grafiche Biesse: Scorzè, Italy, 2001.

34. AA.VV. Arsenale e/è Museo; Atti Della Prima Giornata di Studio per L'istituzione di un Museo Nazionale di Archeologia, Storia ed Etnografia Navale Nell'Arsenale di Venezia, 25 gennaio 2002, Quaderni Insula 11, 4. Available online: http://www.insula.it/index.php/quaderni (accessed on 15 April 2019).

35. Dina, A. (Ed.) La Rinascita Dell'arsenale: La Fabbrica Che si Trasforma; Marsilio: Venezia, Italy, 2004.

36. Città di Venezia. Documento Direttore per l'Arsenale di Venezia-2014; Direzione Patrimonio e Casa. Available online: http://arsenale.comune.venezia.it/?page_id=319 (accessed on 23 February 2019).

37. Rossi, F. I quadri Direttivi dell'Arsenal. In Storia di Venezia, Vol. V, II Rinascimento; Tucci, U., Tenenti, A., Eds.; Società ed Economia, Istituto della Enciclopedia Treccani: Roma, Italy, 1996. 
38. Zan, L.; Deng, K. Micro foundations in the Great Divergence Debate: Opening up the perspective. Account. Hist. 2017. [CrossRef]

39. Ari, B.; Zan, L. Shipbuilding \& early forms of modern management. Comparing Venice \& the Ottomans after Lepanto (1571). Paper Presented at the Workshop Strutture di organizzazione e modello di produzione. Mutazioni e Rappresentazioni. Storia e originalità, Ca' Foscari, Venice, Italy, 27 November 2018.

40. Zan, L.; Bonini Baraldi, S.; Lusiani, M.; Shoup, D.; Ferri, P.; Onofri, F. Managing Cultural Heritage. An International Research Perspective; Routledge: London, UK, 2015.

41. Zan, L.; Yu, B.; Yu, J.; Yan, H. Heritage Sites in Contemporary China: Cultural Policies and Management Practices; Routledge: London, UK, 2018.

42. Zan, L. (Ed.) Per un Futuro dell'Arsenale di Venezia; Cafoscarina: Venezia, Italy, 2018.

43. Zan, L. (Ed.) Il Futuro Dell'arsenale di Venezia. Quale Museo e Quale Accessibilità? Cafoscarina: Venezia, Italy, 2019.

44. Pettigrew, A. The Awakening Giant, Continuity and Change in ICI; Basil Blackwell: Oxford, UK, 1985.

45. Zan, L. Complexity, anachronism and time-parochialism. Doing historical research from a (strategic) management background. Bus. Hist. 2016, 58, 571-596. [CrossRef]

46. Verbix, Online Dictionary. Available online: http://www.verbix.com/webverbix/English/manage.html (accessed on 23 February 2019).

47. The Online Etymology Dictionary, 2010 Douglas Harper. Available online: https://www.etymonline.com/ (accessed on 23 February 2019).

48. Ignoto. Libro Contenente il Maneggio Dell'esecuzione Testamentaria" Sopra la Peza Campo e Prato Regione Dell'eiretta Facciata dal fu sig. Prevosto Raso per Dotar Povere Figlie, Civico Museo Etnografico Ostana-Alta Valle Po.

49. Treccani Online Dictionary. Available online: http://www.treccani.it/vocabolario/maneggio/ (accessed on 23 February 2019).

50. Paciolo, L. Tractatus de' Computis e et Scripturis, 1494. Ristampa Anagrafica Dell'edizione del 1978 della Tip. E Lit; Camilla e Bertolero, Cacucci editore: Roma, Italy, 1987.

51. Drachio, B. Ricordi Intorno la Casa dell'Arsenale, 1586. A.S.Ve, Patroni e Provevditori all'Arsenal, b. 533. Già tra le Carte di Giacomo Contarini; cfr. A.S.Ve, Sala di studio, Indice 311/4. Riprodotto in appendice documentale in Zan et al. 2006; pp. 239-264.

52. Tadini, B. Scrittura de Messer Bortolomio Tadini, 1593, 12 Maggio. A.S.Ve, Patroni e Provveditori all'Arsenal, b. 533; Reproduced in the documentary appendix in Zan et al. 2006; pp. 265-275.

53. Tadini, B. 1594, Scrittura Presentata per Messer Bortolamio Tadini, Rasonato all'Arsenal Nell'eccellentissimo Collegio, adì 19 Zugno 1594. A.S.Ve, Patroni e Provveditori all'Arsenal, b. 533; Reproduced in the documentary appendix in Zan et al. 2006; pp. 276-280.

54. Molin, A. Relatione del Nobil Homo Ser Alvise Molin, Savio agli Ordini, Letta Nell'eccellentissimo Senato. 1633. A.S.Ve, Collegio, Relazioni, b. 57; Reproduced in the documentary appendix in Zan et al. 2006; pp. 345-366.

55. Ansoff, H. Implanting Strategic Management; Prentice-Hall: Englewood Cliffs, NJ, USA, 1984.

56. Pfeffer, J. Renaissance and Renewal in Management Studies: Relevance Regained. Eur. Manag. Rev. 2009, 6, 141-148. [CrossRef]

57. Zan, L. Toward a history of accounting histories. Eur. Account. Rev. 2004, 3, 255-307. [CrossRef]

58. ThoughtCo, History of Accounting from Ancient Times to Today. The Medieval and Renaissance Revolution of Bookkeeping. Available online: https://www.thoughtco.com/history-of-accounting-1991228 (accessed on 23 February 2019).

59. Johnson, H.; Kaplan, R. Relevance Lost: The Rise and Fall of Management Accounting; Harvard Business School Press: Boston, MA, USA, 1987.

60. Chandler, A.D. La Mano Visibile. La Rivoluzione Manageriale Nell'economia Americana; ed orig 1977, Cambridge; Franco Angeli: Milan, Italy, 1981.

61. Chandler, A.D. Gli Stati Uniti: L'evoluzione dell'impresa. In Evoluzione della Grande Impresa e Management; Payne, P.L., Kocka, J., Yamamura, K., Chandler, A.D., Eds.; ed orig Cambridge; Einaudi: Torino, Italy, 1986.

62. March, J. Decisions and Organisations; Basil Blackwell: Oxford, UK, 1988.

63. Czarniawska, B. Organizing: How to study it and how to write about it. Qual. Res. Organ. Manag. 2008, 3, 4-20. [CrossRef] 
64. Menichelli, C. Sviluppo e trasformazione dell'Arsenale di Venezia in funzione della produzione navale. In Arsenale di Venezia. Progetti e Destino; Bosio, M., Fornasiero, T., Gambelli, V., Eds.; Incipit Editore: Conegliano, Italy, 2017; pp. 224-251.

65. Gambelli, V. Trasformazioni recenti: Schedatura e disegni dei progetti realizzati. In Arsenale di Venezia. Progetti e Destino; Bosio, M., Fornasiero, T., Gambelli, V., Eds.; Incipit Editore: Conegliano, Italy, 2017; pp. 62-175.

66. O'Hara, W. Centuries of Success: Lessons from the World's Most Enduring Family Businesses; Adams Media Corporation: Avon, MA, USA, 2004.

67. Family Business, the World's Oldest Family Companies, 2015, September/October. Available online: http://www.griequity.com/resources/industryandissues/familybusiness/oldestinworld.html (accessed on 28 December 2018).

68. Corriere della Sera, Aziende più Antiche al Mondo: Sei Su Dieci Sono Italiane, 6 Gennaio 2009. Available online: https://www.corriere.it/economia/09_gennaio_06/imprese_family_business_classifica_f45457c8-dbf911dd-8581-00144f02aabc.shtml (accessed on 28 December 2018).

69. CSA. Museo della Cultura e della Civiltà del Mare Arsenale di Venezia: Studio di perfettibilità; Versione 3.0; Centro Studi Arsenale: Venice, Italy, 2006.

70. ISMM. Museo Nazionale di Storia Navale. Progetto di Fattibilità; Istituto di Studi Militari Marittimi, internal document: Venice, Italy, 2007.

71. Fontana, G.L. El Arsenal de Venecia. Historia, patrimonio y reutilizacion. In Patrimonio Marítimo, Fluvial y Pesquero; Angel, M., Ed.; CICEES ediciones: Gijon, Spain, 2014; pp. 49-62.

72. Bosio, M.; Fornasiero, T.; Gambelli, V. (Eds.) Arsenale di Venezia. Progetti e Destino; Incipit Editore: Conegliano, Italy, 2017.

73. Tonini, C. Per un museo dell'Arsenale, casa della civiltà, della storia, della marineria di Venezia. In Il Futuro dell'Arsenale di Venezia. Quale Museo e Quale Accessibilità? Zan, L., Ed.; Cafoscarina: Venezia, Italy, 2019.

74. Balzani, R. Per le Antichità e le Belle Arti. La Legge n. 364 del 20 Giugno 1909 e l'Italia Giolittiana; Il Mulino: Bologna, Italy, 2004.

75. Comune di Venezia. Documento Direttore; Relazione tavole illustrative; Comune di Venezia: Venice, Italy, 2000.

76. Jonsen-Verbeke, M. Industrial heritage: A nexus for sustainable tourism development. Tour. Geogr. 1999, 1, 70-85. [CrossRef]

(C) 2019 by the author. Licensee MDPI, Basel, Switzerland. This article is an open access article distributed under the terms and conditions of the Creative Commons Attribution (CC BY) license (http://creativecommons.org/licenses/by/4.0/). 